\title{
腰部椎間板へルニアに対する 椎間板内ステロイド注入療法
}

\author{
伊藤 茂彦 室 捷之 \\ Key words ロ 腰部椎間板ヘルニア (Lumbar disc herniation)， \\ 椎間板内注射療法 (Intradiscal injection therapy)， \\ 神経根ブロック (Nerve root block)
}

\begin{abstract}
要旨 : 腰部椎間板ヘルニアに対する椎間板内ステロイド注入療法 (SIDT と略) につい て述べた．手技自体は椎間板造影の後にステロイド剂を注入するだけのものであり， ベタメサゾン懸濁液を 1 椎間当たり $5 \mathrm{mg}$ 注入を原則として継続してきた．治療効果は $\mathrm{E}$ と $\mathrm{G}$ 合計を有効率とみなした場合，6力月の短期成績で $60.1 \% ， 5$ 年以上の長期成 績で $64.4 \%$ という比較的良好な成績を得た．年齢別では 10 歳台は $31.4 \%$ とやや劣って いたが , 60 歳台は $100 \%$ と非常に優れていた . 神経根ブロックとの比較では，下肢痛 の軽快にはブロックが優位であったが, 腰痛を含めた全般的改善度はSIDTの方が勝 っていた . フランスで問題となったトリアムシノロン注入後の脊柱管内靬帯石灰化と いう副作用に関して，当院でのベタメサゾン使用に対する発生率は $3.8 \%$ で，腰椎下位 三椎間の中で造影剂のみ，何も注入していない椎間にも発生しており，程度も軽く臨 床上問題なく，合併症としての危険性はないと判断した 。
\end{abstract}

\section{Summary}

We evaluated the results of steroid intradiscal injection therapy (SIDT) in patients presenting with lumbar disc herniation. The short term (6 months post injection ) efficacy rate (excellent+good results) was $60.1 \%$, and the long term (more than 5 years post injection) efficacy rate was $64.4 \%$. Sorted by age, efficacy rate was worse at $31.4 \%$ for patients in their teens, with better results achieved for patients in their fiftties and sixties. We were able to determine that for release of low back pain and leg pain, SIDT was more effective than the nerve root block. After SIDT, the incidence and degree of calcification in our patients were significantly lower than those reported in previous studies. Intradiscal injection of betamethasone did not appear to confer any incremental relative risk for lumbar spinal canal calcification based on review of follow-up X-ray.

Shigehiko ITO et al : Intradiscal steroid injection for lumbar disc herniation 岐阜県立多治見病院整形外科〔 
はじめに

椎間板内ステロイド注入療法 (steroid intradiscal injection therapy, 以下 SIDTと略 す)は 1956 年にFefferがハイドロコーチゾン を腰痛患者の椎間板に注入した報告 ${ }^{4,5}$ から 始まっている．本邦では共同演者の室が 1971 年に臨床応用を開始した ${ }^{12)}$. 以後各種 腰痛疾患に対する治療法の1つとしてわれわ れは継続して行っており，症例数もすでに 2,900例を超えた . 今回は光れらのうち腰部 椎間板ヘルニア症例に対する治療の概略につ いて，過去の当院における報告結果 ${ }^{6,7,13)}$ を 総括しながら述べることとする .

\section{I .SIDTの実際}

この治療法の手技自体は，通常の椎間板造 影の後にステロイド剂を追加注入するだけの ものである.穿刺針は $21 \mathrm{G}, 17 \mathrm{~cm}$ 単一針 を使い, ブルーシリンジで造影剂注入時の抵 抗を測る (図 1). 椎間板穿刺経路としては右 外側法を選択している ${ }^{2)}$. L5/S1間の穿刺は， 隣接椎間の刺入部とほぼ同一部位から $30^{\circ}$ 尾 側に針を振れば容易に刺入し得る．またX線 管球か浢尾側方向に振れる透視台ならば，半 側臥位での斜位刺入とすればよい ${ }^{14)}$. 変性 が高度で狭小化が著明な椎間板の穿刺は一見 困難なように感じられるが，椎間板内に線維 輪の断裂が多数存在するために，正確に髄核 中央部を穿刺しなくても，注入薬斉は椎間板 全体に行き渡り却って容易な刺入となる。

以前は入院患者では術前 30 分に, 硫酸ア トロピンとジアゼパムを筋肉注射し, 前投薬 としていたが今では中止し，造影剤も $60 \%$ コンレイ ${ }^{\circledR}$ からイオトロランに変更したが, ステロイド斉は一貫してベタメサゾン懸濁液

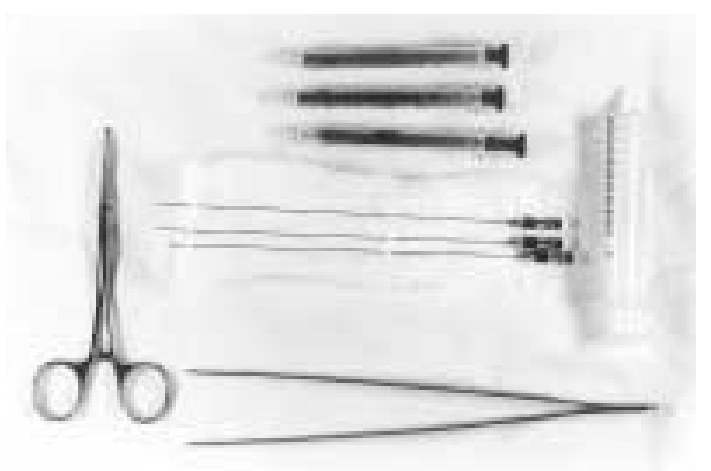

図1 椎間板造影セット. $21 \mathrm{G}, 17 \mathrm{~cm}$ の単一針で椎 間板を穿刺する . 造影剂およびステロイド剂は ブルーシリンジの注射器を用いて注入する . 厳 重な清潔操作が肝要であることはいうまでもな い.

(Rinderon suspension ${ }^{\circledR}$ )を使用している . 注 入量は 1 椎間当たり造影剤 $2 \sim 3 \mathrm{~m} l$ を目安と し, 高度変性椎間板では椎間板内圧の上昇， 疼痛再現性の誘発が得られるように適宜増量 して注入している．ステロイド斉は 1 椎間当 たり $5 \mathrm{mg}$ 注入してきた . 術後の予防的抗生 剂の投与は行ってはいない.

最初の注入は原則として入院加療で行い， 2週の間隔を空けて連続して2回の注入まで で効果を判定する.なお追加注入が必要な場 合は外来にても可能である .

椎間板に感染性疾患の存在が疑われる場合 は適応禁忌で, 重症な糖尿病などの合併症の あるものは血糖値のコントロールが重要であ る.これらの例外を除けば数多くの症例に， 比較的安全に繰り返し行うことができる点に 本法の最大の利点がある .

$$
\text { II. 短期治療成績 (6力月後) }
$$

本法を施行した椎間板へルニア症例は硬膜 外ブロックを含めた従来の保存的治療では効 果がなく, 手術を前提として入院, 検査を行 ったものである . 短期治療成績と遠隔治療成 
表1 腰部椎間板ヘルニアに対するSIDTの短期治療成績

対象：303例, 性別：男性249例, 女性54例, 年齢：16〜65歳, 平均33.7歳

\begin{tabular}{crrrrrrrrr}
\hline 年齢 (歳) & 男 & 女 & 計 & $\mathrm{E}$ & $\mathrm{G}$ & $\mathrm{F}$ & $\mathrm{P}$ & $\mathrm{E}+\mathrm{G}$ & $\%$ \\
\hline$\sim 19$ & 22 & 4 & 26 & 2 & 8 & 4 & 12 & $10 / 26$ & 38.5 \\
$20 \sim 29$ & 86 & 13 & 99 & 16 & 42 & 25 & 16 & $58 / 99$ & 58.6 \\
$30 \sim 39$ & 74 & 11 & 85 & 15 & 40 & 17 & 13 & $55 / 85$ & 64.7 \\
$40 \sim 49$ & 50 & 19 & 69 & 23 & 18 & 18 & 10 & $41 / 69$ & 59.4 \\
$50 \sim 59$ & 15 & 6 & 21 & 3 & 12 & 4 & 2 & $15 / 21$ & 71.4 \\
$60 \sim 69$ & 2 & 1 & 3 & 0 & 3 & 0 & 0 & $3 / 3$ & 100 \\
\hline 計 & 249 & 54 & 303 & 59 & 123 & 68 & 53 & $182 / 303$ & 60.1 \\
$\%$ & 82.2 & 17.8 & 100 & 19.5 & 40.6 & 22.4 & 17.5 & & \\
\hline
\end{tabular}

(文献13より引用)

績とを対比する意味で, SIDT施行後 5 年以 上経過した 303 例を対象として評価した .内 訳は, 男性 249 例，女性 54 例．年齢は $16 〜$ 65 歳, 平均33.7歳であった .

短期成績としては注入後 6 力月での成績を 以下の基準で判定した . Excellent (E)：症状 がほとんど完全に消失し，ADLに支障のな いもの. $\operatorname{Good}(\mathrm{G})$ : 明らかな改善を認め， ADLにほとんど支障はないが, やや再発傾 向を認めるもの . Fair $(F)$ ：改善を認めたが， ADLになお支障を残すもの. Poor $(\mathrm{P})$ ：ほと んど効果のないもの. Worse $(\mathrm{W})$ : 症状か増 悪したもの.

この評価基準による303例の総合短期治療 成績は，E 59例，19.5\%，G 123例，40.6\%， F 68 例，22.4\%，P 53 例 $17.5 \%$ ，Wはなく， $\mathrm{E}+\mathrm{G}$ を有効率とみなした場合 182 例， $60.1 \%$ であった . 性別による有効率に差はなく50 歳台 60 歳台の治療成績は勝っていたが， 10 歳台はやや劣る傾向があった (表1) ${ }^{13)}$.

\section{III . 遠隔治療成績}

遠隔治療成績としては, 短期成績の対象 303 例中 , 5 年以上経過例 178 例についてアン
ケートによる調査を施行した . アンケートは 日整会点数のうち, 自覚症状 3 項目, 計 9 点, ADL 7 項目, 計 14 点の 23 点満点で行った . 23〜22点を $\mathrm{E}, 21 〜 19$ 点を $\mathrm{G}, 18 〜 16$ 点を $\mathrm{F}, 15$ 点以下を $\mathrm{P}$ として評価した .

178例のうち回答のあったものは 126 例で， このうち8例は再発して手術を受けていた . 保存的に経過している 118 例の内訳は男性 93 例，女性 25 例，治療時年齢は $16 \sim 59$ 歳，平 均 34.8 歳で, 経過観察期間は $5 \sim 13$ 年, 平均 9.1 年であった .

総合遠隔治療成績は，E 25例， $21.2 \% ， G$ 51 例，43.2\%，F 25例，21.2\%，P 17例， $14.4 \%$ で $\mathrm{E}+\mathrm{G}$ の有効率は 76 例 , $64.4 \%$ であ つた . 短期治療成績と同樣に 10 歳台の治療 効果がやや劣る傾向があった (表2) ${ }^{13)}$.

\section{IV . 神経根ブロックとの治療効果の差異}

SIDT治療の独自性をみる目的で, 同一症 例における SIDT と神経根ブロック (NRB) の治療効果の差異について検討を加えてみ た. 対象症例は椎間板へルニア38例 40 椎間 で, 神経根ブロックの方が下肢痛の軽快には 優位な効果を示していたが, 腰痛を含めた全 
表 2 腰部椎間板ヘルニアに対するSIDTの 遠隔治療成績 (平均経過観察期間 9.1年)

対象：118例，性別：男性93例，女性25例， SIDT 時年齢：16 59 歳, 平均 34.8 歳

\begin{tabular}{crrrrcc}
\hline 年齢 (歳) & $\mathrm{E}$ & $\mathrm{G}$ & $\mathrm{F}$ & $\mathrm{P}$ & $\mathrm{E}+\mathrm{G}$ & $\%$ \\
\hline$\sim 19$ & 2 & 1 & 2 & 2 & $3 / 7$ & 42.9 \\
$20 \sim 29$ & 8 & 19 & 8 & 4 & $27 / 38$ & 69.2 \\
$30 \sim 39$ & 6 & 19 & 6 & 4 & $25 / 35$ & 71.4 \\
$40 \sim 49$ & 7 & 8 & 6 & 4 & $15 / 25$ & 60.0 \\
$50 \sim 59$ & 2 & 4 & 3 & 3 & $6 / 12$ & 50.0 \\
\hline 計 & 25 & 51 & 25 & 17 & $76 / 118$ & 64.4 \\
\hline \multicolumn{5}{c}{ (文献13より引用) }
\end{tabular}

表3 除痛効果（腰部椎間板ヘルニア症例に対して）

\begin{tabular}{|c|c|c|}
\hline \multirow[t]{4}{*}{ SIDT } & 効果 あり & 32 椎間 (80 \%) \\
\hline & なし & 8椎間 (20 \% ) \\
\hline & 腰 ·臀部痛 & 26 椎間 $(65 \%)$ \\
\hline & 下肢痛 & 25 椎間 $(62.5 \%)$ \\
\hline \multirow[t]{4}{*}{ NRB } & 効果 あり & 35 根 $(87.5 \%)$ \\
\hline & なし & 5 根 (12.5\%) \\
\hline & 腰 ·臀部痛 & 6 根 $(15 \%)$ \\
\hline & 下肢痛 & 33 根 $(62.5 \%)$ \\
\hline
\end{tabular}

(文献7より引用)

表 4 石灰化症例の一覧

\begin{tabular}{|c|c|c|c|c|c|c|}
\hline & & 高位 & 石灰化 & 追跡期間 & ステロイド & 追加手術 \\
\hline 1. 男 & 21 & $\mathrm{~L} 4 / 5$ & 発生 & 5 年 2 力月 & + & Love \\
\hline 2. 女 & 36 & $\mathrm{~L} 4 / 5$ & 発生 & 10 年 3 力月 & - & \\
\hline 3. 男 & 53 & $\mathrm{~L} 5 / \mathrm{S}$ & 発生 & 7 年 & + & (L4/5 Love) \\
\hline 4. 女 & 15 & L5/S5 & 増大 & 5 年 7 力月 & + & Love \\
\hline 5. 男 & 32 & $\mathrm{~L} 3 / 4$ & 増大 & 9 年6 カ月 & + & (L4/5 Love) \\
\hline \multirow[t]{2}{*}{ 6. 女 } & 45 & $\mathrm{~L} 3 / 4$ & 増大 & 6 年 11 力月 & - & \\
\hline & & $\mathrm{L} 4 / 5$ & 増大 & 6 年 11 力月 & + & Love \\
\hline 7. 女 & 66 & $\mathrm{~L} 4 / 5$ & 増大 & 7 年 1 カ月 & + & \\
\hline
\end{tabular}

般的改善度はSIDTの方が勝っていた (表 3) ${ }^{7)}$.

\section{V . SIDT 後の脊柱管内石灰化について}

さて1991年以降特にフランスでトリアム シノロン注入後の脊柱管内勒帯石灰化という SIDTによる合併症の報告 ${ }^{1,3)}$ が相次いだ， 逆にL'huillierの報告 ${ }^{10)}$ のように，石灰化が 消失したという全く相反するものもあるため に自験例に検討を加えた 。

SIDT後 1 年以上経過観察した椎間板へル ニアおよび脊柱管狭窄症例 183例，498椎間 を対象とした .

これらのうち 7 例 8 椎間， $3.8 \%$ に後方線維 輪外層部ないしは後縦鞋帯の石灰化像の発生
あるいは増大を見た . 全例椎間板へルニア症 例であるが，うち2例，2椎間は造影剂のみ の注入であった . 3 例にはSIDT後隣接椎間 の髄核摘出術が行われていた $(\text { 表 } 4)^{8)}$.

発生例， 21 歳男性，昭和 62 年 5 月 22 日に L4/5, L5/S 2 椎間のSIDTを行った . 経過は 良好であったが, 5 年 2 力月後に腰・下肢痛 を再発し OPLLとともにL4/5の髄核摘出術 を行った(図2).

石灰化群と非石灰化群の年齢層に差は認め なかったが，観察期間は 5 年 2 カ月〜 10 年 3 力月, 平均 88.3 力月と石灰化群の方が比較的 長期間にわたっていた .

注入椎間の隣接椎間も含めた, 腰椎下位 3 椎間の観察からは, 薬剂を全く注入していな 

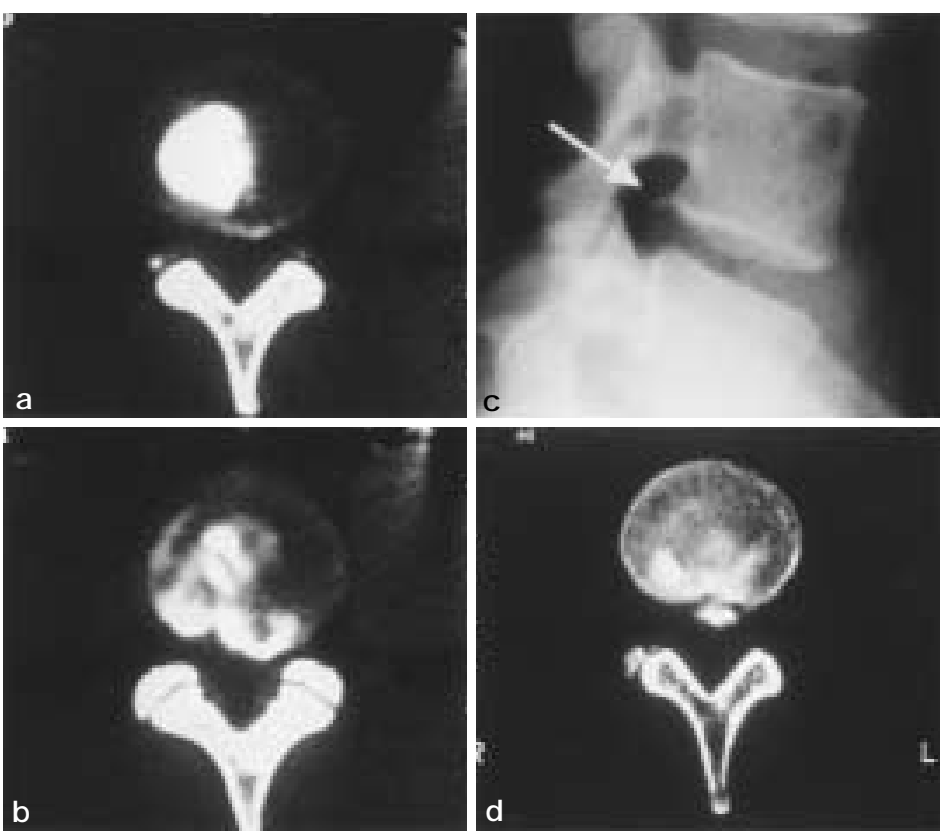

図2 石灰化発生例.21歳男性

$\mathrm{a}, \mathrm{b}: \mathrm{SIDT}$ 時のCTディスコグラフィー像

$\mathrm{c}, \mathrm{d}: \mathrm{SIDT}$ 後, 5 年 2 力月でOPLL (矢印)の発生を認めた .

表 5 椎間高位と注入薬剂

\begin{tabular}{lllll}
\hline & 薬剂なし & 造影剂 & \multicolumn{3}{c}{ 造影剂 +ステロイド } \\
\hline L3/4 & $34(1)$ & $98(1)$ & $51(1)$ & $183(3)$ \\
& $1.64 \%$ & & & \\
$\mathrm{~L} 4 / 5$ & 2 & $41(1)$ & $140(3)$ & $183(4)$ \\
& $\begin{array}{l}2.19 \% \\
\mathrm{~L} 5 / \mathrm{S}\end{array}$ & & & \\
& 16 & 54 & $113(2)$ & $183(2)$ \\
& $1.09 \%$ & & & \\
\hline & $52(1)$ & $193(2)$ & $304(6)$ & $549(9)$ \\
& $1.92 \%$ & $1.04 \%$ & $1.97 \%$ & $1.64 \%$ \\
\hline
\end{tabular}

（）; 石灰化例 X ${ }^{2}$-test N.S. (文献8より引用)

いL3/4の1椎間にも石灰化が発生していた (表5) .

$$
\mathrm{VI} \text {. 考 察 }
$$

近年行われている椎間板内注入療法での使 用薬剂は，(1)抗炎症剂，(2)椎間板の容量・内 圧を減少させる薬斉の2つに分けられ，ステ ロイドは前者の代表であり，Chymopapain

\section{が後者の代表である .}

今回報告したSIDTの作用機序としては， (1) anti-inflammatory effect of corticosteroids itself, (2) alkaline effect, (3) polymerizing effect, (4) local control of autoimmune reaction があげられており 9,15,17) , (1)(2)がヘルニアに よる神経根の急性炎症を消退させ , (3)(4)がへ ルニア病態の予後に好影響を与えるものでは ないかと推測される。

SIDTの初期効果は, 薬剂がヘルニアと神 経根の病巣へdirectに浸潤して効果を発現す るため, 硬膜外注入, 神経根ブロックと異な りより直接的である.このことは, 椎間板造 影像で epidural leakingの有無が治療成績と 必ずしも相関しなかった報告 ${ }^{11)}$ からも明ら かである．また自験例における神経根ブロッ クとの治療効果の差異からの検討7)でも示 された . 
遠隔成績についてみると，前述した(3)(4)の 作用がどの程度関与しているかは残念ながら 明らかでない．しかも近年の報告にもあるよ うに , 炎症反応の沈静化とともにヘルニア腫 瘤の自然吸収をも抑制する可能性もあるた め ${ }^{16)}$, 弚の詳細に関しては再考の余地があ る。

注入療法後の石灰化という副作用に関して は, 自験例の検討からは使用するステロイド 剂，強いては添加物の違いからか，過去の報 告例と比べて発生率も低く，石灰化の程度は ごく軽度で臨床上大きな問題はなく合併症と しての危険性はないと判断した ${ }^{8)}$. 自験例で は発生までの期間の長さ，隣接椎間の手術の 影響, 造影剂単独注入椎間板での発生などを 考慮に入れると, 石灰化は椎間板変性の一過 程でのものと考えるのが妥当であろう .

これらの点を踏まえても，SIDTの臨床的 効果は十分期待できるものであり，また本法 は Chymopapainによる Chemonucleolysis と 本質的に異なり，腰部椎間板へルニアのほと んどすべての症例に対して安全に，かつ，ま た反復施行することが可能であるという利点 を有し，一般的な保存的治療て効果のない椎 間板ヘルニアに対する特異的な保存的治療法 として位置づけることができる．もちろん真 の治療効果を知るためには, prospectiveな double blind studyが必要であることは論を 俟たない .

$$
\text { まとめ }
$$

SIDTですべての椎間板ヘルニアの治療を 試みたり，手術治療を決して否定し得るもの ではないが, SIDTは椎間板造影プラスアル フアの簡便な手技と考えられ，椎間板へル二 ア治療過程の中で, 一度は試みられてもよい
選択肢の1つと考えて引き続き施行してい る。

\section{文献}

1) Bazin T, Vigon E, Mathieu $P$ et al. Intradiscal treatment of patients with intractable low back pain: a controlled double-blind study comparing aprotinin, corticosteroid and placebo. Presented at the International Intradiscal Therapy Society Fifth Annual Meeting. 1992 ; Nice, France, April, 8-12.

2) Brown JE. Clinical studies on chemonucleolysis. Clin Orthop. 1969; 67 : 94-99.

3) Debiasis F, Bontoux D, Alcalay $M$ et al. Calcification after intra-disk injection of triamcinolone hexacetonide in lumbar disk hernia: evaluation of therapeutical results. Rev Rhum Mal Osteoartic. 1991 ; $58: 565-570$.

4) Feffer LH. Treatment of low-back and sciatic pain by the injection of hydrocortisone into degenerated intervertebral discs. J Bone Joint Surg. 1956 ; 38A : 585-592.

5) Feffer LH. Therapeutic intradiscal hydrocortisone. -A long-term study-. Clin Orthop. 1969 ; $67: 100-104$.

6) Ito S, Yamada Y, Tsuboi S et al. Intradiscal injectin of corticosteroids for the treatment of low back pain in middle-aged and aged patients. Neuro-Orthopedics. 1991; 12:85-91.

7) 伊藤茂彦, 室 捷之ほか. 腰部椎間板ステロイ ド注射療法と腰部神経根ブロック療法の治療効 果の差異について . 中部整災誌 . 1996 ; 39 ： 637-638.

8) Ito S, Usui H, Maruyama K et al : Roentgenographic evaluation of ossification and calcification of the lumbar spinal canal after intradiscal betamethasone injection. J Spinal Disord. 2001 ; $14: 434-438$.

9) Leao L. Intradiscal injection of hydrocortisone and prednisolone in the treatment of low back pain. Rheumatism. $1960 ; 16: 72-77$.

10) L'huiller F, Chevrot A, Vallée C et al. Lumbar root pain and calcified herniated disc. J Radiol. 1988; 69:763-766.

11) 室 捷之, 錦見純三, 浅井夫三武ほか. 腰部椎 間板ヘルニア症に対する椎間板内ステロイド注 入療法の効果発現機序に関する一考察 ; 特に硬 
膜外腔流出像との関連性について (椎間板内注 射療法 第8報). 中部整災誌. $1978 ; 21: 1221-$ 1223.

12) 室 捷之 . 腰部椎間板へルニアに対する椎間板 内ステロイド注入療法 . 手術 . 1987；41：17531760.

13) 室 捷之 . 腰痛疾患に対する椎間板内薬物注入 療法一光の現況と将来への展望一。岐阜医誌 $1990 ; 3: 33-47$.

14）佐藤哲朗，平田 晋, 金淵隆人. 腰椎, 胸椎椎 間板穿刺のための斜位直接刺入法 . 臨整外 .
$1989 ; 24: 1439-1447$.

15) 関 昌彦. 腰椎椎間板へルニアに対する椎間板 内ステロイド注入療法の検討 . 整形外科. 2002 ; 53:507-511.

16) 志津直之, 吉澤英造, 小林 茂ほか. 椎間板組 織が神経根に及ぼす影響. 脊椎脊髄 . 1997；10： 969-981.

17) Wilkinson HA, Schuman N. Intradiscal corticosteroids in the treatment of lumbar and cervical disc problems. Spine. 1980 ; $5: 385-389$. 